\title{
EVALUASI KELAYAKAN USAHATANI BERAS MERAH (Oryza Nivara) DI DESA MANIS RAYA KECAMATAN SEPAUK KABUPATEN SINTANG
}

\author{
MASTORDIANTO ${ }^{1)}$, ADI SUYATNO ${ }^{2)}$, MASWADI $^{2)}$ \\ 1) Mahasiswa Magister Agribisnis Fakultas Pertanian \\ Universitas Tanjungpura Pontianak \\ 2) Dosen Pembimbing, Staf Pengajar Program Studi Magister Agribisnis \\ Fakultas Pertanian Universitas Tanjungpura \\ Email : Puspitarini2210@gmail.com
}

\begin{abstract}
Manis Raya village is one of the villages in the subdistrict of Sepauk having production of Oryza Nivara is large enough. The size of the production Oryza Nevara does not yet guarantee a high income are accepted by farmers. Production of Oryza Nevara obtained in the village Manis Raya relatively hight, does not mean the income is also hight, so that required a research analisis income and feasibility farming of Oryza Nivara in the village of Manis Raya. Research aims to know the income and feasibility farming of Oryza Nivara that was held in April until June 2018. The determination of locations have done by deliberately (purposive) with consideration that the village of Manis Raya is one of producer Oryza Nivara. The analysis used in this research was income analysis and feasibility. The result of the analysis showed that the average income of Oryza Nivara farmers for one growing season is Rp. 17.098.414 /ha mt growing season. The analysis showed revenue of cost ratio was 4,54, thus, Oryza Nivara farm in the village of Manis Raya worth to be the efforted.

Keywords: Analysis of income, farming Oryza Nivara, feasibility analysis.
\end{abstract}

\section{PENDAHULUAN}

Di Indonesia, sektor pertanian merupakan sektor yang sangat berperan dalam pembangunan ekonomi nasional. Hal tersebut dapat dilihat dari kontribusinya terhadap PDB (Produk Domestik Bruto), penyerapan tenaga kerja, dan penghasil devisa. PDB sektor pertanian termasuk pula kehutanan dan perikanan adalah sebesar 63,8 triliun rupiah pada tahun 1996, nilai ini terus meningkat menjadi 66,4 triliun rupiah pada tahun 2000. Besarnya PDB pertanian tersebut memberikan kontribusi sekitar 17 persen terhadap PDB nasional.

Menurut Mosher dalam Mangunwidjaya dan Sailah (2009 : 27) mengemukan bahwa salah satu syarat mutlak pembangunan pertanian adalah adanya teknologi usahatani yang senantiasa berubah. Oleh sebab itu penggunaan teknologi dalam usahatani padi sawah sangat dibutuhkan oleh petani dengan harapan dapat meningkatkan produktifitas, meningkatkan efisiensi usaha, menaikkan nilai tambah produk yang dihasilkan serta meningkatkan pendapatan petani. Salah satu komoditas utama pertanian kita adalah padi karena padi merupakan kebutuhan pokok penduduk kita. Komoditi ini tumbuh hampir di seluruh daerah di Indonesia. Mengingat pentingnya komoditi ini sebagai bahan makanan pokok, kiranya pengembangan komoditi padi membutuhkan perhatian khusus. Di kebanyakan daerah, usahatani padi diusahakan dengan secara 
tradisional secara turun temurun (Suratiyah,2008). Padi merupakan bahan makanan yang menghasilkan beras. Bahan makanan ini merupakan bahan makanan pokok bagi sebagian besar penduduk indonesia. Meskipun padi dapat diganti oleh makanan lain, namun padi memiliki nilai tersendiri bagi orang yang biasa makan nasi dan tidak dapat dengan mudah diganti oleh makanan lain (Suger, $2001:$ 16).

Padi beras merah merupakan salah satu jenis padi di Indonesia yang mengandung gizi yang tinggi. Berdasarkan hasil penelitian, beras merah mempunyai khasiat yang lebih dibandingkan dengan beras putih. Padi beras merah sangat baik untuk daerah rawan pangan khususnya masyarakat yang berstatus kurang gizi. Selain itu, konsumsi beras merah dapat mencegah penyakit kanker, kolestrol dan jantung koroner dengan biaya relatif sangat murah dan aman. Namun demikian, di Indonesia padi beras merah kurang mendapatkan perhatian bila dibandingkan padi beras putih, bahkan konsumsi padi beras merah di Indonesia sangat terbatas. Banyak penelitian yang menyatakan bahwa beras merah memang kaya akan kandungan nutrisi, diantaranya, protein, asam lemak tidak jenuh, betasterol, isoflavon, saponin, Zn, dan juga mevinolin-HMG-CoA. Oleh karena itu, jika beras merah dibudidayakan secara organik merupakan salah satu pilihan yang tepat dan salat satu tanaman pangan yang baik untuk perbaikan gizi masyarakat. Selain itu, kesejahteraan petani akan meningkat.

Kenyataannya banyak para petani yang belum merasakan seutuhnya keuntungan secara signifikan dari usaha padi beras merah yang telah diusahakannya. Sehingga diperlukan adanya suatu usaha untuk mengetahui secara rinci dalam kaitannya dengan pendapatan yang diperoleh oleh petani. Berdasarkan uraian tersebut di atas, maka penulis merasakan perlu melakukan penelitian tentang Evaluasi Usahatani Beras Merah ( Oryza Nivara) di Desa Manis Raya Kecamatan Sepauk Kabupaten Sintang.

Adapun tujuan penelitian ini adalah untuk mengetahui pendapatan Petani padi Beras Merah di Desa Manis Raya Kecamatan Sepauk Kabupaten Sintang. Dan untuk mengetahui kelayakan usahatani padi beras merah di Desa Manis Raya Kecamatan Sepauk Kabupaten Sintang.

\section{METODE PENELITIAN}

Metode yang digunakan dalam penelitian ini adalah studi kasus pada Desa Manis Raya Kecamatan Sepauk Kabupaten Sintang, sebagaimana layaknya sebuah studi kasus, maka pengkajian secara mendalam ditujukan pada suatu obyek secara mendalam baik lingkungan sosial maupun manusia yang berada didalamnya. Dalam pelaksanaannya dilakukan dalam bentuk penelitian deskriptif, dalam presentasi data yang diperoleh diharapkan dapat menjelaskan secara terperinci dan mendalam obyek yang diteliti.

Penelitian ini dilaksanakan di Desa Manis Raya Kecamatan Sepauk Kabupaten Sintang. Pemilihan lokasi ini ditentukan secara sengaja (Purposive), dengan dasar pertimbangan bahwa dilokasi tersebut merupakan salah satu potensi besar komoditi beras merah dan Desa Manis Raya merupakan pusat pemasaran di Kecamatan Sepauk. Sedangkan waktu pengambilan data rencananya mulai Bulan Maret 2018 sampai dengan selesai.

Teknik pengambilan data yang digunakan dalam penelitian ini adalah metode survey dan wawancara.Teknik pengambilan data dilakukan dengan dua 
jenis data, yaitu data primer dan data sekunder. Data primer diperoleh dari hasil wawancara langsung dengan respon dan serta menggunakan daftar kuesioner.Sedangkan untuk data sekunder diperoleh dari literatur-literatur yang terkait dengan penelitian ini dan data sekunder yang tersedia di Kantor Dinas Pertanian dan Perkebunan di Kabupaten Sintang. Variabel atau objek penelitian yang menjadi titik perhatian penelitian ini adalah pendapatan rumah tangga dari usaha tani beras merah.

1. Produksi adalah jumlah total gabah kering hasil panen padi sawah dalam satu tahun (2 musim tanam), diukur dengan satuan kilogram (Kg).

2. Luas lahan, yakni luasan lahan yang digunakan untuk mengusahakan usahatani di ukur dengan satuan hektar (Ha). Satu hektar stara dengan $10.000 \mathrm{M}^{2}$.

3. Benih yaitu jumlah pemakaian benih padi yang digunakan untuk usahatani oleh petani dalam satu tahun (2 kali musim tanam), diukur dengan satuan kilogram $(\mathrm{Kg})$.

4. Tenaga kerja adalah jumlah tenaga kerja yang digunakan untuk menjalankan usahatani mulai dari persiapan lahan hingga pasca panen dalam satu tahun, diukur dengan satuan hari orang kerja (HOK).

Pendapatan petani padi dalam penelitian ini dibedakan atas pendapatan biaya tunai, pendapatan biaya total dan pendapatan tunai. Pendapatan atas biaya tunai diperoleh dari pengurangan penerimaan total usaha tani dengan biaya tunai yang benar-benar dikeluarkan dalam bentuk uang tunai atau pendapatan atas biaya yang benar-benar dikeluarkan oleh petani (explicit cost). Pendapatan tunai adalah pendapatan dari hasil penerimaan tunai dalam bentuk uang tunai setelah dikurangi oleh biaya tunai. Penerimaan tunai didapat dari penerimaan total yang dikurangi dengan penerimaan diperhitungkan yang merupakan penerimaan atas nilai produksi dari jumlah fisik produk yang dikonsumsi sendiri. Pendapatan tersebut dirumuskan sebagai berikut (Hantari, 2007):

$$
\pi_{\text {biaya tunai }}=P_{\text {total }}-B_{\text {tunai }} \pi_{\text {biaya total }}=P_{\text {total }}-B_{\text {tunai }}-B_{\text {diperhitungka }}
$$

$$
\pi_{\text {tunai }}=P_{\text {tunai }}-B_{\text {tunai }}-B_{\text {diperhitung }}
$$

Dimana :

$\pi_{\text {biaya tunai } \quad=\text { pendapatan atas biaya tunai }}$

$B_{\text {tunai }}=$ biaya tunai $(\mathrm{Rp})$.

$\pi_{\text {biaya total }}=$ pendapatan atas biaya total $(\mathrm{Rp})$.

$B_{\text {diperhitungkan }}=$ biaya diperhitungkan (Rp).

$\pi_{\text {tunai }}=$ pendapatan dari penerimaan tunai $(\mathrm{Rp})$.

$P_{\text {tunai }} \quad=$ penerimaan tunai $(\mathrm{Rp})$.

$P_{\text {total }} \quad=$ penerimaan total $(\mathrm{Rp})$.

\section{HASIL DAN PEMBAHASAN}

Kecamatan Sepauk secara geografis terletak diantara 0014 menit Lintang Utara dan 00 31 menit Lintang Selatan serta diantara 110025 menit bujur timur dan 111022 menit Bujur timur.

- Sebelah Utara berbatasan dengan Kabupaten Sekadau dan Kecamatan Ketungau Hilir.

- Sebelah Selatan berbatasan dengan Kabupaten Ketapang dan Kabupaten Melawi.

- Sebelah Timur berbatasan dengan Kecamatan Tempunak dan Kabupaten Melawi.

- Sebelah Barat berbatasan dengan Kabupaten Sekadau. 
Kecamatan Sepauk memiliki luas wilayah $1.825,70 \mathrm{Km} 2$ atau 8,44 persen dari wilayah Kabupaten Sintang. Letak administratif Kecamatan Sepauk meliputi 40 Desa, 105 Dusun dan 308 RT, dengan Desa luas terbesar adalah Desa Nanga Sepauk sekitar 6,27 persen dan Desa dengan luas terkecil adalah desa Bungkung Baru yaitu sekitar 0,81 persen dari luas Kecamatan Sepauk.

Karakteristik Responden

Tabel 1. Karakteristik Responden

\begin{tabular}{lcc}
\hline Variabel Sosio-Demografi & Frekuensi (Orang) & Presentase (\%) \\
\hline Umur Responden & 11 & 37 \\
27 - 35 tahun & 10 & 33 \\
36 - 45 tahun & 9 & 30 \\
46 - 39 tahun & & \\
Pendidikan Terakhir & 20 & 67 \\
SD & 6 & 20 \\
SLTP & 4 & 13 \\
SLTA & 10 & \\
Pengalaman Bertani & 9 & 33 \\
3-5 tahun & 7 & 30 \\
6-8 tahun & 4 & 23 \\
9-11 tahun & & 14 \\
12-14 tahun & 15 & 50 \\
Luas Lahan & 15 & 50 \\
0,5 ha & & \\
1 ha & &
\end{tabular}

Sumber: Analisis Data Primer, 2018

Dari Tabel 1 menunjukan bahwa umur responden petani padi beras merah yang terbesar pada kelompok umur 27-35 tahun sebanyak 11 orang dengan persentase $36,67 \%, 36-45$ tahun sebanyak 10 orang dengan persentase $33,33 \%$, 46-53 tahun sebanyak 9 orang dengan persentase 30,00\%, Undang-Undang No.13 Tahun 2003 disebutkan bahwa tenaga kerja yang produktif tingkat umurnya 15-64 tahun. Dengan demikian usahatani padi sawah di Desa Manis Raya masih didominasi oleh petani yang produktif yaitu 30 orang dengan persentase $100 \%$.

tingkat pendidikan petani yang yang paling banyak adalah SD yaitu sebanyak 20 orang atau 66,67 \%, sementara petani yang berpendidikan SMP dan SMA sebanyak 6 dan 4 orang saja atau hanya 20\% dan 13,33\%, jadi dapat dikatakan petani responden di Desa Manis Raya masih berpendidikan rendah, untuk itu dituntut kerja keras penyuluh pertanian dalam membimbing petani agar dapat merubah pola pikir sehingga dapat menerima inovasi baru. Mosher dalam Saputra, (2012) mengatakan bahwa tingkat pendidikan menjadi suatu faktor penentu dalam pengembangan usaha dan meningkatkan produktivitas, secara umum, apabila tingkat pendidikan tinggi maka produktivitas juga tinggi.

Pengalaman bertani responden petani padi sawah di Desa Manis Raya memiliki pengalaman yang cukup dalam bidangnya. Hernanto dalam saputra (2012), pengalaman bertani merupakan modal dalam upaya mengembangkan usahatani, pengalaman bertani berperan dalam proses seorang aktivitas petani. Semakin lama melakukan aktivitas usahatani maka akan semakin berpengalaman, hal ini terjadi karena proses yang memerlukan pembelajaran sehingga pengalaman 
bertani berperan pada peningkatan produksi. Luas lahan yang dimiliki 30 responden petani padi ladang adalah seluas $22,5 \mathrm{Ha}$. Petani yang memiliki luas lahan 0,5 ha sebanyak 15 orang dengan persentase $50 \%$, luas lahan $1 \mathrm{Ha}$ sebanyak 15 orang dengan persentase $50 \%$. Rata-rata setiap petani memiliki lahan seluas $0,75 \mathrm{Ha}$. Luas lahan sangat mempengaruhi petani dalam penerimaan dan penerapan teknologi sebagai upaya peningkatan hasil produksi. Makin luas lahan usahatani membutuhkan pengelolaan dan biaya yang tinggi, hal ini sesuai dengan teori Mubyarto dalam Ikbal, (2014). Tidak ada petani yang menyewa lahan untuk mengusahakan padi beras merah, karena tanah yang mereka gunakan adalah milik sendiri.

\section{Usahatani Padi Beras Merah Di Desa Manis Raya Kecamatan Sepauk Budidaya Padi Beras Merah}

- Persiapan Lahan Tanam Padi Beras Merah

Pertama, siapkan terlebih dahulu lahan tanam yang akan digunakan untuk menanam padi beras merah. Lahan yang efisien untuk menanam padi beras merah adalah sawah. Sebelum proses penanaman dilakukan sebaiknya bersihkan lahan tanam dari gulma dan tanaman pengganggu laiinya. Selanjutnya, lahan tanam digemburkan dengan cara dicangkul atau dibajak.

- Persiapan Bibit Padi Beras Merah

Benih bibit beras merah dapat diperoleh dengan membelinya di toko pertanian. Pilihlah benih bibit yang unggul dan juga berkualitas. Jika sudah diperoleh, selanjutkan rendam benih bibit tersebut dalam air. Jika ada bibit yang mengapung buang, karena hal tersebut menandakan benih bersebut kurang baik. Setelah itu, lakukan penyemaian bibit padi beras merah pada lahan persemaian yang telah disiapkan

- Penanaman Padi Beras Merah

Setelah bibit telah berumur 21 hari, bibit dapat dipindahkan ke lahan tanam yang sudah disiapkan. Penanaman padi beras merah ini sebaiknya dilakukan pada awal musim hujan.

- Pemeliharaan Tanaman Padi Beras Merah

Perawatan yang dilakukan pada tanaman padi beras merah sama halnya dengan pemeliharaan tanaman padi biasa yaitu seperti pemberian pupuk, penyulaman, penyiangan, irigasi, pengendalian hama dan penyakit. Jika ada tanaman yang mati atau tumbuh tidak optimal, lakukan penyiangan dengan menggantinya dengan bibit yang baru. Penyulaman ini sebaiknya dilakukan pada saat tanaman berumur 1-3 minggu agar tanaman tumbuh serempak. Jika ada gulma atau tanaman pengganggu lainnya yang tumbuh di sekitar tanaman padi beras merah maka segera lakukan penyiangan, penyiangan ini dilakukan pada saat tanaman beras merah berumur 3-4 minggu danm 8 minggu. Lakukan pula pengendalian hama dan penyakit dengan cara menyemprotkan pestisida.

Pemberian pestisida tersebut kurang lebih dilakukan setiap 15 hari sekali. Agar kebutuhan nutrisi yang dibutuhkan tanaman padi beras merah terpenuhi, maka lakukan pemupukan. Pemupukan tersebut dapat dilakukan dengan menggunakan pupuk organik (pupuk kandang) maupun pupuk anorganik (urea, TSP dan KCL). Pemberian pupuk organik atau pupuk kandang diberikan setelah tanaman berumur tiga minggu setelah tanam. Sedangkan pupuk anorganik yang diberikan dapat berupa pupuk urea, TSP dan KCL. Pupuk TSP dan KCl diberikan saat tanam dan urea pada 3-4 minggu dan 8 minggu setelah tanam. 
- Masa Panen Padi Beras Merah

Pemanenan atau umur panen padi merah yaitu sekitar 5-6 bulan setelah tanam. Cara panen padi beras merah, sama halnya seperti pemanenan padi pada umumnya.

- Persiapan lahan dan penanaman

Lahan pertanian merupakan penentu dari pengaruh faktor produksi komoditas pertanian. Secara umum dikatakan, semakin luas lahan (yang digarap/ditanami), semakin besar jumlah produksi yang dihasilkan oleh lahan tersebut. Pentingnya faktor produksi lahan bukan saja dilihat darisegi luas atau sempitnya lahan, tetapi juga segi lain, misalnya aspek kesuburan tanah, macam penggunaan lahan (tanah sawah, tegalan dan sebagainya) dan topografi (tanah dataran pantai, endah dan dataran tinggi).

Padi beras merah merupakan salah satu jenis padi di Indonesia yang mengandung gizi yang tinggi. Berdasarkan kandungan gizinya maka padi beras merah sangat baik untuk daerah rawan pangan khususnya masyarakat yang berstatus kurang gizi. Padi dengan kadar protein tinggi sangat bermanfaat dalam perbaikan gizi masyarakat. Beberapa zat gizi umumnya ditemukan di beras merah termasuk vitamin E, thiamin, magnesium, vitamin B6, dan serat. Selain itu, ada sekitar selusin lebih banyak vitamin dan mineral yang ditemukan dalam beras merah.

Lahan yang digunakan oleh responden adalah lahan milik sendiri. Proses penanaman dilakukan bersama-sama dengan petani tersebut secara bergotong royong secara bergiliran sehingga tidak memakan biaya yang banyak hanya petani yang memiliki lahan padi beras merah tersebut menyiapakan makan saja untuk bersama-sama. Proses penanaman dilakukan setahun sekali dan dilakukan secara berpindah-pindah.

- Pemeliharaan (Pemupukkan dan pengendalian hama)

Pemupukan merupakan kegiatan penambahan unsur hara yang dibutuhkan tanaman padi. Kegiatan pemupukan dilakukan dengan cara menebarkan pupuk pada lahan yang ditanami padi agar pertumbuhan tanaman optimal dan menghasilkan gabah yang berkualitas baik. Jenis pupuk yang digunakan oleh petani di Desa Manis raya adalah Urea, NPK dengan jumlah pupuk sesuai dengan luasan lahan yang diusahakan dan kemampuan keuangan petani. Pemupukan menggunakan pupuk Urea dilakukan pada saat masa pertumbuhan tanaman padi atau seminggu setelah penanaman dilakukan. Sedangkan pemupukan menggunakan pupuk NPK dilakukan pada saat padi berumur 30 hari setelah tanam. Kegiatan pemupukan dilakukan oleh tenaga kerja dalam keluarga untuk meminimalisir penggunaan biaya produksi.

- Panen dan pasca panen

Panen pada usahatani padi adalah proses pengambilan hasil padi setelah masuk waktu panen yang ditandai dengan menguningnya bulir padi pada malai, bila bulir padi ditekan terasa keras, dan bila dikupas bulir gabah bewarna merah. Proses panen padi sawah di Desa Manis Raya dilakukan dengan cara memotong pada bagian tengah batang padi kemudian dikumpulkan di satu tempat yang selanjutnya gabah akan dirontokan menggunakan alat Power Tresser. Setelah dirontokan gabah dimasukan ke dalam karung untuk selanjutnya dikeringkan. Proses panen padi di Desa manis Raya dilakukan secara gotong royong untuk mempercepat proses pemanenan dan menghemat biaya yang dikeluarkan. 


\section{Biaya usahatani padi beras merah}

\section{Biaya Tetap}

\section{- Biaya Tenaga Kerja}

Tenaga kerja dalam hal ini petani merupakan faktor penting dan perlu diperhitungkan dalam proses produksi komoditas pertanian. Tenaga kerja harus mempunyai kualitas berpikir yang maju seperti petani yang mampu mengadopsi inovasi-inovasi baru, terutama dalam menggunakan teknologi untuk pencapaian komoditas yang bagus sehingga nilai jual tinggi. Penggunaan tenaga kerja dapat dinyatakan sebagai curahan tenaga kerja. Curahan tenaga kerja adalah besarnya tenaga kerja efektif yang dipakai. Usahatani yang mempunyai ukuran lahan berskala kecil biasanya disebut usahatani skala kecil, dan biasanya pula menggunakan tenaga kerja keluarga. Lain halnya dengan usahatani berskala besar, selain menggunakan tenaga kerja luar keluarga juga memiliki tenaga kerja ahli. Ukuran tenaga kerja dapat dinyatakan dalam harian orang kerja (HOK),sedangkan dalam analisis ketenagakerjaan diperlukan standarisasi tenaga kerja yang biasanya disebut dengan hari kerja setara pria (HKSP).

Tenaga kerja yang digunakan dalam usahatani padi beras merah berasal dari tenaga kerja dalam keluarga dan luar keluarga. Biaya tenaga kerja dalam keluarga merupakan biaya yang diperhitungkan dimana biaya tersebut secara tunai tidak dikeluarkan, sedangkan biaya tenaga kerja di luar keluarga menggunakan sistem upah dibayar tunai dan dikeluarkan. Pemakaian tenaga kerja dihitung berdasarkan upah harian yang dikonversikan ke dalam hari orang kerja (HOK). Pemakaian tenaga kerja wanita dihitung sama dengan upah tenaga pria, yaitu Rp 100.000,- per hari untuk pengolahan lahan, Pada penanaman dilakukan dengan gotong royong.

Tabel 2. Biaya Tenaga Kerja Dalam Keluarga Pengelolaan Padi Ladang/Ha/Periode

\begin{tabular}{lllccc}
\hline No & Keterangan & Satuan & $\begin{array}{c}\text { Upah } \\
\text { (Rp) }\end{array}$ & $\begin{array}{c}\text { Jumlah } \\
\text { (HOK) }\end{array}$ & Total \\
\hline 1 & Pengolahan lahan & Harian & 100.000 & 9,45767 & 945.767 \\
4 & Penanaman & Harian & 100.000 & 6,17675 & 617.675 \\
6 & Penyiangan & Harian & 100.000 & 10,87133 & 1.087 .133 \\
7 & Panen & Harian & 100.000 & 8,522 & 852.200 \\
8 & Pasca Panen & Harian & 100.000 & 4,179 & 417.900 \\
\hline \multicolumn{2}{r}{ Jumlah } & & $\mathbf{5 0 0 . 0 0 0}$ & $\mathbf{3 9 , 2 0 6 7 5}$ & $\mathbf{3 . 9 2 0 . 6 7 5}$ \\
\hline
\end{tabular}

Sumber:Analisis Data Primer, 2018

Tabel diatas menunjukan biaya tenaga kerja dalam keluarga yang diperhitungkan yaitu sebesar Rp.3.920.675,-. Biaya terbesar adalah penyiangan sebesar Rp.1.087.133,- karena pada penyiangan dibutuhkan banyak tenaga kerja. Biaya terkecil adalah pasca panen sebesar Rp.417.900,-, karena pada kegiatan ini tidak membutuhkan banyak pekerja.

\section{Biaya Penyusutan Barang}

Peralatan yang digunakan dalam usahatani padi Ladang di Desa Manis Raya adalah cangkul dan parang. 
Tabel 3. Rata-rata Biaya Alat dan Penyusutan Alat/Ha/Periode Produksi

\begin{tabular}{ccccccc}
\hline No & Keterangan & Jumlah & $\begin{array}{c}\text { Harga/ } \\
\text { Unit }\end{array}$ & Total & $\begin{array}{c}\text { Umur } \\
\text { Ekonomis } \\
\text { (tahun) }\end{array}$ & Penyusutan \\
\hline 1 & Cangkul & 3 & 45.000 & 135.000 & 2 & 45.000 \\
2 & Parang & 3 & 30.000 & 90.000 & 2 & 30.000 \\
\hline & Jumlah & $\mathbf{6}$ & $\mathbf{7 5 . 0 0 0}$ & $\mathbf{2 2 5 . 0 0 0}$ & $\mathbf{4}$ & $\mathbf{7 5 . 0 0 0}$ \\
\hline
\end{tabular}

Sumber: Analisis Data Primer, 2018

Dari tabel 3 diatas bahwa total biaya peralatan adalah Rp.225.000,- dengan rincian jumlah dari pembelian alat-alat dikalikan dengan harga alat yang dibutuhkan untuk pengolahan padi beras merah. Dalam usahatani padi beras merah terdapat beberapa peralatan yang dihitung biaya penyusutanya tergantung dengan umur ekonomis peralatan yang digunakan petani di Desa Manis Raya. Biaya penyusutan peralatan sebesar Rp.75.000,-.

\section{- Biaya pengangkutan}

Biaya pengangkutan yang dikeluarkan oleh petani adalah biaya pengangkutan padi beras merah yang akan dijual dari kebun usahatani padi beras merah sampai ke pedagang pengumpul. Walaupun sebagian besar petani menjual ke padagang pengumpul keliling, namun ada juga petani yang menjual ke pedagang pengumpul desa. Dimana petani tidak ada biaya pengeluaran untuk transportasi ke pasar karena para pembeli langsung ke lokasi tempat bertanam.

\section{Biaya Variabel}

- Biaya Benih

Biaya yang dikeluarkan untuk benih tergantung pada luas lahan yang dikerjakan.

Tabel 4. Rata-Rata Biaya Benih Usahatani Beras Merah

\begin{tabular}{ccccc}
\hline No & Luas Lahan & $\begin{array}{c}\text { Benih yang } \\
\text { diperlukan }(\mathrm{kg})\end{array}$ & $\begin{array}{c}\text { Harga Satuan } \\
\text { (Rupiah) }\end{array}$ & Jumlah (Rupiah) \\
\hline 1. & $1 \mathrm{Ha}$ & 40 & 15.000 & Rp. 600.000 \\
2. & $0,5 \mathrm{Ha}$ & 20 & 15.000 & Rp. 300.000 \\
\hline & Jumlah & $\mathbf{6 0 ~ k g}$ & $\mathbf{3 0 . 0 0 0}$ & $\mathbf{1 . 8 0 0 . 0 0 0}$ \\
\hline
\end{tabular}

Sumber: Analisis Data Primer

Penerimaan dan Pendapatan Usahatani Padi Beras Merah

Penerimaan usaha tani adalah jumlah uang yang diterima dari penjualan usaha taninya. Sedangkan pendapatan adalah jumlah uang yang tersisa setelah penerimaan dikurangi biaya yang dikeluarkan maupun yang diperhitungkan. Penerimaan usahatani padi beras merah dengan harga jual rata-rata yang diterima petani adalah Rp. 21.650/kg.

Besarnya pendapatan yang diterima petani merupakan hasil dari jumlah produksi padi saat musim panen dikali dengan harga jual padi saat musim panen dengan satuan harga Rp. $21.650 / \mathrm{kg}$ dikurangi dengan total biaya yang terdiri dari biaya tetap dan biaya variabel. Dimana biaya tetap terdiri dari biaya perawatan seperti biaya peralatan tani dan biaya lain-lain, sedangkan biaya variabel terdiri dari biaya pengadaan bibit, biaya pembeliaan obat atau pestisida, dan biaya tenaga kerja. Besarnya pendapatan responden petani padi sawah dihitung dengan menggunakan rumus sebagai berikut:

$$
\mathrm{P}=\mathrm{TR}-\mathrm{TC}
$$


Tabel 5. Produksi dan Penerimaan Usahatani Padi Beras Merah per hektar di Desa Manis Raya Kecamatan Sepauk

\begin{tabular}{ccrr} 
Luas Lahan & $\begin{array}{c}\text { Rata-Rata Produksi } \\
(\mathbf{K g} / \mathbf{H a})\end{array}$ & $\begin{array}{c}\text { Rata-Rata } \\
\text { Harga (Rp) }\end{array}$ & $\begin{array}{c}\text { Rata-Rata Total } \\
\text { Penerimaan }\end{array}$ \\
\hline $1 \mathrm{Ha}$ & 1,353 & 21,566 & $29,126,666$ \\
$0,5 \mathrm{Ha}$ & 683.3 & 21,733 & $14,743,33$ \\
\hline
\end{tabular}

Sumber: Analisis Data primer, 2018

Dari tabel 5 diatas dapat kita lihat bahwa rata rata penerimaan dengan luas lahan $1 \mathrm{Ha}$ tanaman padi beras merah yaitu sebesar Rp. 29,126,666,- dengan jumlah produksi rata rata $1.353 \mathrm{Kg} / \mathrm{Ha}$ dan harga jual rata-rata Rp.21,566,sedangkan rata-rata penerimaan dengan luas lahan 0,5 Ha dengan jumlah produksi rata-rata $683,3 \mathrm{Kg} / \mathrm{Ha}$ dan harga jual rata-rata $\mathrm{Rp} .21 .733$ dan rata-rata penerimaan Rp. 14.743.333,-. Banyaknya Produksi dan Penerimaan pada usahatani beras merah berdasarkan tabel di atas begantung pada luas lahan dan berapa banyak biaya yang dikeluarkan serta harga jual beras merah tersebut.

Tabel 6. Penerimaan dan Pendapatan Usahatani Padi Beras Merah per hektar di Desa Manis Raya Kecamatan Sepauk

\begin{tabular}{cccr}
\hline Luas Lahan & $\begin{array}{c}\text { Total Biaya } \\
\text { Rata-Rata (Rp) }\end{array}$ & $\begin{array}{c}\text { Total Penerimanaan } \\
\text { Rata-Rata (Rp) }\end{array}$ & $\begin{array}{c}\text { Total Pendapatan } \\
\text { Rata-Rata (Rp) }\end{array}$ \\
\hline $1 \mathrm{Ha}$ & $4,836,252$ & $21,935,000$ & $17,098,414$ \\
$0,5 \mathrm{Ha}$ & $4,065,790$ & $14,743,333$ & $10,677,543$ \\
\hline
\end{tabular}

Sumber: Analisis Data Primer, 2018.

Pada Tabel 6 dapat dilihat bahwa pendapatan rata-rata pada luas lahan 1 ha tanaman padi beras merah yaitu sebesar 17,098,414 dengan total biaya rata-rata Rp. 4,836,252,- dan total penerimaan rata-rata Rp. 21,935,000-. Pada luas lahan 0,5 ha tanaman padi beras merah pendapatan rata-rata yaitu sebesar 10,677,543,dengan total biaya rata-rata Rp. 4,065,790,- dan total penerimaan rata-rata $\mathrm{Rp}$. 14,743,333,-. Penerimaan dan pendapatan masing-masing petani bervariasi tergantung pada luas lahan dan banyaknya biaya produksi yang dikeluarkan.

Tabel 7 Analisis Pendapatan Usahatani Rata-rata Padi Beras Merah Selama Satu Kali Musim Tanam Di Desa Manis Raya Kecamatan Sepauk Kabupaten Sintang, 2017

\begin{tabular}{|c|c|c|}
\hline No & Uraian & Nilai \\
\hline \multirow{13}{*}{$\begin{array}{l}1 . \\
2 . \\
3 . \\
4 .\end{array}$} & Produksi Padi Beras Merah & 1.018 \\
\hline & Harga Padi Beras Merah & Rp. 21.650,- \\
\hline & Penerimaan & Rp. 21.935.000,- \\
\hline & Biaya & \\
\hline & a. Biaya Usahatani & Rp. $3.939 .252,-$ \\
\hline & - Biaya Pengolahan Lahan & Rp. 945.767,- \\
\hline & - Penanaman & Rp. 617.675,- \\
\hline & - Pemupukan 1 & - \\
\hline & - $\quad$ Pemupukan 2 & - \\
\hline & - Penyiangan & Rp. 1.087.133,-- \\
\hline & - Penyemprotan & \\
\hline & - Panen & Rp. 852.200,- \\
\hline & - Pasca Panen & Rp. 417.900,- \\
\hline
\end{tabular}




\begin{tabular}{rll}
\hline & b. Biaya Produksi & Rp. 897.000,- \\
& $\bullet$ Benih & Rp. 557.967,- \\
& $\bullet$ Pupuk & - \\
& - Alat Cangkul & Rp. 93.067,- \\
& - Alat Parang & Rp. 163,567,- \\
& - Karung & Rp. 82.400,- \\
& - Peptisida & \\
& - Herbisida & \\
5. Total Biaya (a + b) & \\
$6 . \quad$ Pendapatan $(3-5)$ & Rp. 4.836.252,- \\
\hline
\end{tabular}

Sumber: Analisis Data Primer, 2018

\section{KESIMPULAN}

- Produksi rata-rata padi beras merah di Desa Manis Raya Kecamatan Sepauk Kabupaten Sintang diperoleh dari responden sebanyak 30 orang dengan jumlah luas lahan 22,5 ha total produksi rata-rata adalah $2036,3 \mathrm{Kg}$ sehingga rata-rata Produksi padi beras merah per ha adalah $1.018 \mathrm{Kg}$.

- Sedangkan Harga rata-rata padi beras merah diperoleh dari Total harga jual oleh responden ke pengumpul adalah Rp. 649.500,- sehingga untuk harga rata-rata dari 30 orang responden adalah Rp. 21,650 -.

- Total Penerimaan rata-rata adalah Total Produksi rata-rata dikalikan dengan Total harga rata-rata penjualan, dimana dari hasil pengolahan responden didapatkan Total Penerimaan adalah sebesar Rp. 658.050.000,- sehingga jika dirata-ratakan dari 30 responden Penerimaan rata-rata nya adalah sebesar Rp. 21.935.000,-.

- Biaya Usahatani rata-rata dari hasil responden adalah Total dari biaya usahatani responden sebesar Rp. 118.177.570,- sehingga biaya usahatani ratarata dari 30 responden adalah Rp. 3.939.252,- .

- Biaya Produksi rata-rata adalah Total Biaya Produksi yang telah dikeluarkan oleh petani responden sebanyak 30 orang sebesar Rp. 26.910.000,- sehingga rata-rata biaya produk adalah sebesar Rp. 897.000,-.

- Total Biaya rata-rata adalah total biaya rata-rata usahatani + total biaya produksi rata-rata, yaitu: Rp.3.939.252,- + Rp. 897.000,- = Rp. 4.836.586,- .

- Sehingga total pendapatan rata-rata petani padi beras merah di Desa Manis Raya Kecamatan Sepauk Kabupaten Sintang adalah total penerimaan rata-rata - total biaya rata-rata, yaitu Rp. 21.935 .000 - Rp. $4.386 .586=\mathrm{Rp}$. 17.098.414.,- dan permusim tanam (6 bulan) adalah Rp. 2.849.735,- per bulannya.

Berdasarkan hasil penelitian, diketahui bahwa besar kecilnya pendapatan usahatani padi beras merah yang diterima oleh petani dipengaruhi oleh penerimaan dan biaya produksi. Jika produksi dan harga jual padi semakin tinggi, maka akan meningkatkan penerimaan. Apabila biaya produksi lebih tinggi dari penerimaan maka akan menyebabkan kerugian usaha para petani. Adapun pendapatan bersih yang diterima petani di Desa Manis Raya berdasarkan hasil penelitian rata-rata pendapatan padi beras merah adalah Rp. 2.849.736,- /MT, yang merupakan hasil pengurangan jumlah penerimaan dengan jumlah biaya yang 
dikeluarkan selama satu musim tanam padi beras merah.. Diharapkan petani dapat menekan biaya produksi, terutama pada biaya benih, dan biaya tenaga kerja.

\section{DAFTAR PUSTAKA}

Arum, Winanti Puspa. 2016. Evaluasi Kelayakan Usaha dan Nilai Tambah Agroindustri Tempe (Studi Kasus pada Agroindustri Tempe di Pekon Podomoro dan Kelurahan Pringsewu Selatan, Kecamatan Pringsewu, Kabupaten Pringsewu). Skripsi Fakultas Pertanian. Universitas Lampung. Bandar Lampung.

Dinas Pertanian dan Perkebunan Balai Penyuluh Pertanian (BPP). 2016. Program Penyuluhan Pertanian. Kecamatan Sepauk Kabupaten Sintang. BPP.

Badan Pusat Statistik (BPS). 2016. Survei Sosial Ekonomi Nasional. BPS. Jakarta.

Badan Pusat Statistik(BPS). 2011. Sensus Pertanian. Kabupaten Sintang : BPS Sintang - Kalimantan Barat.

Endro, S. 2009, Hasil Penelitian Terdahulu tentang pendapatan usahatani Tanaman Padi. http://www.agrimart.com.

Febriana, Risa Bilqis. 2016. Evaluasi Dampak Ekonomi Pelaksanaan Program Pengembangan Agribisnis Perdesaan di Gapoktan Karya Tani Desa Bendosewu Kabupaten Blitar. Tesis Fakultas FISIP. Universitas Airlangga.Surabaya.

Hafsah, Mohammad Jafar. 2004. Potensi, Peluang, dan Strategi Pencapaian Swasembada Beras dan Kemandirian Pangan nasional Melalui Produksi Mantap. Jakarta. Deptan.

Karlina, A. 2010. Penerapan PSAK Nomor 23 Dalam Pengakuan dan Pengukuran Pendapatan Pada PT. Prodia Widyahusada Wilayah-I Medan. Skripsi Fakultas Ekonomi, Universitas Sumatera Utara. Medan.

Mangunwidjaya, D. dan Sailah, I. 2009. Pengantar Teknologi Pertanian. Penebar Swadaya. Jakarta.

Nasution. 2003. Metode Penelitian Naturalistik Kualitatif. Bandung: Tarsito.

Nitisemito, 1991. Wawasan Studi Kelayakan dan Evalusi Proyek. Bumi Aksara. Jakarta.

Noor, H., Faizal. 2007. Ekonomi Majerial. Jakarta : Raja Grafindo Persada.

Qohar, Rizqi Ardhini. 2014. Analisis Kelayakan Pengembangan Usaha Beras Merah Organik (Studi Kasus : UD Sirtanio, Banyuwangi, Jawa Timur). Skripsi Fakultas Ekonomi dan Manajemen. Institut Pertanian Bogor. Bogor.

Rahman, Arief. 2015). Evaluasi Aspek Fungsi Tanaman Pada lanskap Jalan Kampus Universitas Sam Ratulangi. Skripsi Fakultas Pertanian, Universitas Sam Ratulangi, Manado.

Regiawandi, Regi . 2011. Evaluasi Program PUAP Di Desa Wonosari Kabupaten Karanganyar. Skripsi Fakultas Pertanian Universitas Sebelas Maret. Surakarta.

Saputra, Riyan. 2016. Evaluasi Kesesuaian Lahan Untuk Pengembangan Jeruk Gerga Kabupaten Lebong. Skripsi Fakultas Pertanian. Universitas Bengkulu. Bengkulu.

Santoso, Taufan Sukmo 2008. Analisis Finansial Usaha Krupuk. Tesis Fakultas Sains dan Teknologi. Universitas Islam Negeri Syarif Hidayatullah Jakarta. Jakarta. 
Shinta, A., 2005. Ilmu Usahatani. Diktat Kuliah Jurusan Sosial Ekonomi Pertanian Fakultas Pertanian Universitas Brawijaya. Malang.

Shintawati, Ayu. 2003. Evaluasi program pembagian beras untuk keluarga miskin (raskin) di kabupaten Sukoharjo (studi kasus dua desa). Skripsi Fakultas Ekonomi. Universitas Sebelas Maret. Surakarta.

Suger, HR. 2001. Bercocok Tanam Padi. CV. Aneka Ilmu. Anggota IKAPI.

Suratiyah, K. 2008. Ilmu Usahatani. Penebar Swadaya. Jakarta.

Soekartawi. 1996. Analisis Usaha Tani. UI. Press. Jakarta

Widarda, Mohamad Dodo. 2016. Evaluasi Program KRPL Di Desa Menes. Skripsi Fakultas Ilmu Sosial dan Ilmu Politik, Universitas Sultan Ageng Tirtayasa. Serang.

Wahyuninsih, Dewi Hermawati. 2015. Evaluasi Program Pelatihan Pengolahan Hasil Pertanian Di Balai Latihan Kerja Kabupaten Sukoharjo. Skripsi Fakultas Teknik, Universitas Negeri Yogyakarta. Yogyakarta.

Yunita, Yuma. 2014. Evaluasi Keberhasilan Program Beras Untuk Rumah Tangga Miskin (Program Raskin) dan Manfaatnya Bai Rumah Tangga Sasaran Penerima Manfaat (RTS-PM) di Kecamatan IV Nagari Bayang Utara Kabupaten Pesisir Selatan. Skripsi Fakultas Pertanian. Universitas Andalas. Padang.

Yustiarni, Amelia Kartika. 2011. Evaluasi Kemitraan dan Analisis Pendapatan Usahatani Penangkaran Benih Padi Bersertifikat. Skripsi Fakultas Ekonomi dan Manajemen. Institut Pertanian Bogor. Bogor.

Zulfahri (2017). Evaluasi Dukungan InfraStruktur Kawasan Agropolitan Di Kabupaten Bantaeng. Skripsi Fakultas Sain dan Teknologi. Universitas Islam Negeri Alauddin Makasar. 